\title{
Actions of Salbutamol in Late Pregnancy: Plasma Cyclic AMP, Insulin and C-Peptide, Carbohydrate and Lipid Metabolites in Diabetic and Non-Diabetic Women
}

\author{
B. B. Fredholm, N. O. Lunell, B. Persson, and J. Wager \\ Department of Pharmacology, Karolinska Institute, Department of Obstetrics at Huddinge University Hospital, Department of Paediatrics \\ at St. Görans Hospital, Karolinska Institute, Stockholm, Sweden
}

\begin{abstract}
Summary. Salbutamol was administered intravenously in doses increasing from 3.75 to $22.5 \mu \mathrm{g} / \mathrm{min}$ to 5 non-diabetic and 7 diabetic women in the last trimester of pregnancy. In diabetic as well as nondiabetic women the diastolic blood pressure fell progressively with increasing doses, and the systolic BP and heart rate increased at doses above $7.5 \mu \mathrm{g} / \mathrm{min}$. The effect on fetal heart rate was less pronounced than the effect on maternal heart rate. Cyclic AMP levels in plasma were similar in non-diabetic and diabetic women before salbutamol. Twenty min following $3.75 \mu \mathrm{g} / \mathrm{min}$ a significant increase was seen in both groups. The peak increase (3-5 fold) was higher in the diabetic than in the non-diabetic women. Plasma insulin and C-peptide levels rose in a dosedependent manner in the non-diabetic and four of the diabetic women. However, in three of the diabetic women the insulin level was unaffected by salbutamol and C-peptide was almost undetectable. Plasma concentrations of glucose, glycerol, NEFA and 3-HB were higher in the diabetics than in the non-diabetics before salbutamol and the elevations induced by salbutamol were also significantly larger in the diabetic women. The present data show that salbutamol in doses employed clinically may cause pronounced metabolic effects, especially in diabetic women, and it is suggested that when intravenous infusion of salbutamol is given to pregnant diabetic women not only cardiovascular but also some metabolic variable such as glucose should be carefully monitored.
\end{abstract}

Key words: Cyclic AMP, insulin $\beta_{2}$-adrenergic agonists, diabetes, pregnancy and metabolism.

Selective $\beta_{2}$-adrenoceptor agonists have found an increasing use in obstetrics to prevent premature labour $[17,25,27,29,31,34]$. While the cardiovascular side effects of this therapy have received attention
$[27,29]$ the possible metabolic side effects have not been extensively studied. However, two recent studies have shown that salbutamol infusion to non-diabetic pregnant women induced a marked increase of plasma insulin, C-peptide and glucose together with an increased rate of lipolysis $[28,39]$. It is known that diabetes leads to an increased responsiveness to $\beta$ adrenoceptor agonists $[2,5,14]$. Except for an occasional case report [37], there is no information about the effect of $\beta$-adrenergic agonists on insulin secretion, lipid and carbohydrate metabolism in pregnant diabetic women.

Stimulation of $\beta$-adrenergic receptors leads to activation of the adenyl-cyclase system and enhanced generation of cyclic AMP, which is assumed to lead to different physiological responses such as uterine relaxation and different metabolic effects $[4,35]$. It has been shown that agents which increase intracellular cyclic AMP formation also lead to elevated levels of plasma cyclic AMP [7].

The aim of the present study was to compare the effects of salbutamol in non-diabetic and diabetic pregnant women. Changes in plasma cyclic AMP, concomitant changes in lipid and carbohydrate metabolites in blood and their relation to changes in degree of insulin secretion were also studied. The object was also to estimate the additional metabolic deterioration that could be expected in a clinical situation when this drug is given to a pregnant diabetic.

\section{Material and Methods}

\section{Patients}

Twelve women participated in the study, which was approved by the regional ethical committee. Salbutamol was administered in the morning after an overnight fast. All women were given salbutamol because of various pregnancy disorders such as premature 
Table 1. Clinical data on mothers and infant

\begin{tabular}{|c|c|c|c|c|c|c|c|c|c|c|c|}
\hline \multirow[b]{2}{*}{$\begin{array}{l}\text { Subject } \\
\text { no }\end{array}$} & \multicolumn{6}{|c|}{ Mother } & \multicolumn{5}{|l|}{ Infant } \\
\hline & Age & $\begin{array}{l}\text { Height } \\
(\mathrm{cm})\end{array}$ & $\begin{array}{l}\text { Pre- } \\
\text { pregn. } \\
\text { weight } \\
(\mathrm{kg})\end{array}$ & $\begin{array}{l}\text { Weight } \\
\text { gain } \\
\text { kg }\end{array}$ & $\begin{array}{l}\text { White's } \\
\text { class }^{c}\end{array}$ & $\begin{array}{l}\text { Gest. } \\
\text { age at } \\
\text { testing } \\
\text { (days) }\end{array}$ & $\begin{array}{l}\text { Birth } \\
\text { weight } \\
\text { (g) }\end{array}$ & $\begin{array}{l}\text { Length } \\
(\mathrm{cm})\end{array}$ & $\begin{array}{l}\text { Gesta- } \\
\text { tional } \\
\text { age } \\
\text { (days) }\end{array}$ & $\begin{array}{l}\text { Apgar } \\
\text { score } \\
1^{\prime} 4^{\prime}\end{array}$ & Clinical course \\
\hline 1 & 30 & 159 & 58 & 16.8 & $\mathrm{D}$ & 224 & $\sigma^{\top} 3300$ & 53 & 231 & & IUD $^{\mathrm{a}}$ \\
\hline 2 & 24 & 167 & 92 & 5.3 & B & 258 & Q2230 & 47 & 259 & 810 & uneventful \\
\hline 3 & 30 & 161 & 50 & 8.4 & A & 243 & $\$ 2850$ & 59 & 275 & 1010 & uneventful \\
\hline 84 & 37 & 171 & 59 & 5 & $\mathrm{D}$ & 236 & $\sigma^{7} 3090$ & 49 & 264 & 1010 & uneventful \\
\hline 范 5 & 28 & 160 & 45 & 10.9 & $\mathrm{D}$ & 228 & $\sigma^{113420}$ & 50 & 260 & 710 & uneventful \\
\hline है 6 & 31 & 162 & 61 & 10.5 & $\mathrm{C}$ & 241 & $0^{7} 3630$ & 50 & 258 & 99 & uneventful \\
\hline $\bar{\rho} 7$ & 39 & 168 & 58.5 & 11.5 & B & 258 & $\sigma^{\top} 3400$ & 51 & 266 & 910 & uneventful \\
\hline $\mathscr{\mathscr { C }} 8$ & 18 & 163 & 63 & 7.5 & & 242 & $q 3050$ & 50 & 284 & 1010 & uneventful \\
\hline 远 9 & 23 & 163 & 62 & 8.5 & & 259 & $O^{7} 3450$ & 51 & 264 & 1010 & uneventful \\
\hline 哥 10 & 25 & 161 & 66 & 3.9 & & 237 & 82830 & 50 & 275 & 910 & uneventful \\
\hline ક 11 & 23 & 175 & 69 & 14.2 & & 249 & $\$ 2170$ & 44 & 254 & 48 & $\mathrm{SFD}^{\mathrm{b}}$ \\
\hline$\sum 12$ & 25 & 167 & 60 & 20.9 & & 211 & $\$ 3390$ & 51 & 286 & 99 & uneventful \\
\hline
\end{tabular}

a IUD $=$ intrauterine death week 34

b $\quad$ SFD $=$ small for date infant

c see ref. 42

contraction, bleeding and in one case proteinuria. Clinical data on the women and the newborn infants are given in Table 1 . As shown in Table 1 all women, except subject no 2 , had a normal weight in relation to length, 7 women were diagnosed as diabetics. Two of these women $[3,7]$ were gestational diabetics with an IV, glucose tolerance $\mathrm{k}$-value of less than $1 \% / \mathrm{min}$ during pregnancy which reverted to normal after delivery. All except one of the diabetic women (pat. no. 3) were given insulin in doses between 6 and 164 $\mathrm{U} /$ day.

\section{Procedure}

Indwelling catheters were placed in each brachial vein. One of these was used for blood sampling at regular $20 \mathrm{~min}$ intervals. When control samples at $-20 \mathrm{~min}$ and $0 \mathrm{~min}$ had been collected the infusion of salbutamol was started via the other brachial vein. The rate of infusion was $3.75 \mu \mathrm{g} / \mathrm{min}$ for $20 \mathrm{~min}, 7.5$ $\mu \mathrm{g} / \mathrm{min}$ for $20 \mathrm{~min}, 15 \mu \mathrm{g} / \mathrm{min}$ for $20 \mathrm{~min}$ and finally $22.5 \mu \mathrm{g} / \mathrm{min}$ for another $20 \mathrm{~min}$. Fetal heart rate was continuously monitored by cardiotachymeter (Corometrics, USA). Maternal blood pressure and pulse rate was taken every five minutes. Blood samples were taken every $20 \mathrm{~min}$. For lactic acid determination samples were drawn directly into ice-cooled 0.6 $\mathrm{mol} / \mathrm{l}$ perchloric acid. Cyclic AMP was determined in blood samples drawn into tubes containing disodiumEDTA (final concentration 5-10 mmol/l). Blood samples for the other variables were drawn into heparin-containing tubes. After centrifugation the plasma or the protein free supernatant was stored frozen until assay.

\section{Chemical Determinations}

All determinations were carried out in duplicate. Lactic acid was measured according to Cramp [9], glucose with a glucose-oxidase method (Glox, AB Kabi, Sweden), glycerol fluorimetrically [21], NEFA colorimetrically [22], 3-hydroxybutyrate (3-HB) fluorimetrically [32], insulin by radioimmunoassay (Phadebas, Pharmacia, Sweden), C-peptide by radioimmunoassay [16] with reagents obtained from Novo Research Institute (Copenhagen, Denmark). The presence of insulin antibodies in the insulin treated diabetic women was tested in 5 of the women by the method described by Heding [15]. In none of them could antibodies be detected. Cyclic AMP was determined essentially according to Brown et al. [8] using binding protein prepared from bovine adrenal cortex. $\left({ }^{3} \mathrm{H}\right)$-adenosine $3^{\prime}, 5^{\prime}$-cyclic monophosphate $(27 \mathrm{Ci} /$ mmol) was obtained from the Radiochemical Centre (Amersham, England). The assay contained $0.1 \mathrm{~mol} /$ $1 \mathrm{NaCl}$ and $1 \mathrm{~g} / 1$ bovine serum albumin to minimize the influence of salts and protein in the samples and $5 \mathrm{mmol} / \mathrm{l}$ disodium EDTA to inhibit phosphodiesterase. The samples were measured either undiluted or diluted $1: 5$ in assay buffer. The results were identical. $92 \pm 6$ per cent of the binding activity could be removed by phosphodiesterase (Boehringer, Mannheim, BRD) treatment. 


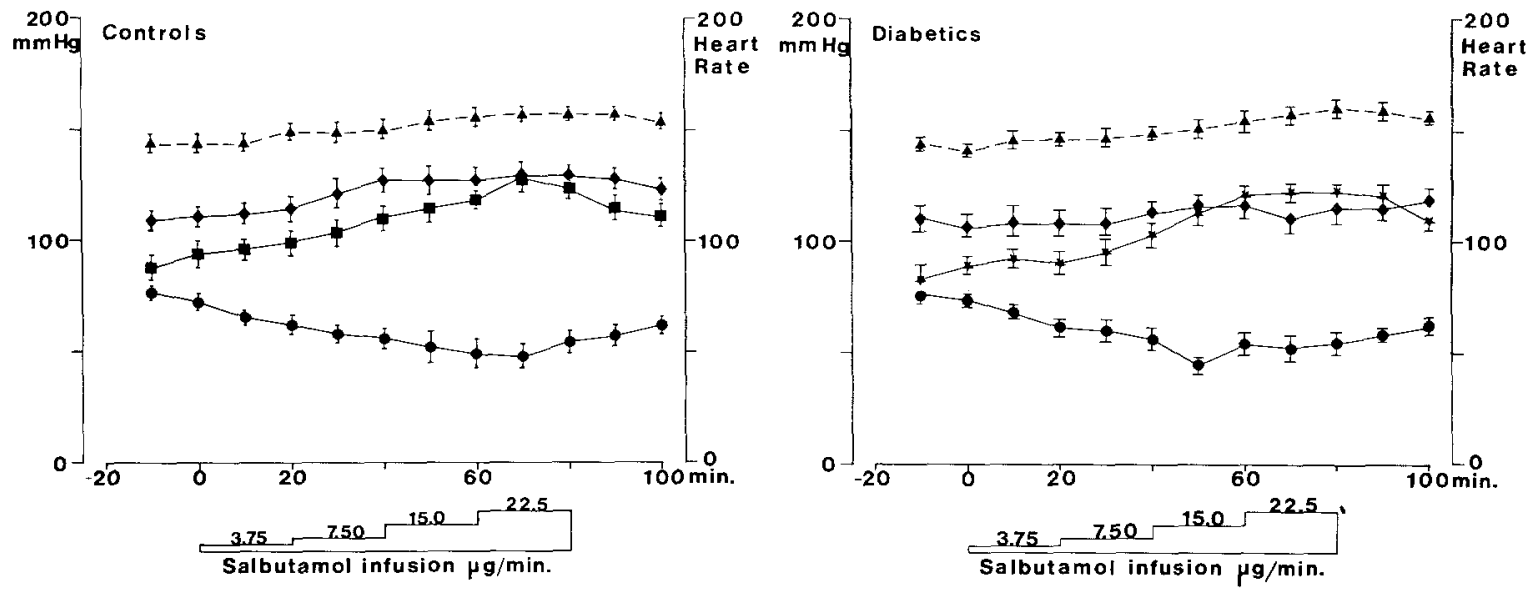

Fig. 1. Cardiovascular effects of salbutamol. 1 a. Maternal diastolic and systolic blood pressure, maternal and fetal heart rate in 5 nondiabetic women. Mean \pm SEM.1b. The same variables in 7 diabetic women. $\longrightarrow$ Systolic blood pressure, D—Diastolic blood pressure

Statistical Evaluation. Means, standard deviations and standard errors of the mean were computed with conventional methods. Statistical hypotheses were tested by Student's t-test for paired (where applicable) or unpaired variates or by conventional linear correlation analysis. In order to guard against the possibility that non-normal distribution of variates had invalidated the statistical analysis, non-parametric methods were also employed (Wilcoxon-test and Corner-test for association). Since no principal differences were found, the results of the more powerful parametric tests are given.

\section{Results}

\section{Cardiovascular Responses}

Following salbutamol infusion maternal diastolic blood pressure fell, the systolic blood pressure, fetal and maternal heart rate increased (Fig. 1a, 1b). There were no statistically significant differences in any of these variables between diabetic and non-diabetic subjects. The diastolic blood pressure was significantly decreased $10 \mathrm{~min}$ after the lowest dose of salbutamol $(\mathrm{p}<0.05$ in the control group and $\mathrm{p}<$ 0.01 in the group of diabetic women). By contrast the systolic blood pressure was significantly increased only after 40 min infusion $(\mathrm{p}<0.05)$ in the control group and after 50 min of infusion $(\mathrm{p}<0.01)$ in the diabetic group. Maternal heart rate was increased 30 min following the start of infusion in both groups ( $\mathrm{p}$ $<0.01)$, and fetal heart rate was increased in both groups only after $40 \mathrm{~min}$ of infusion $(\mathrm{p}<0.05)$. The maximal decrease in diastolic blood pressure was 24 $\mathrm{mm} \mathrm{Hg}(34 \%)$. The maximal increase in systolic

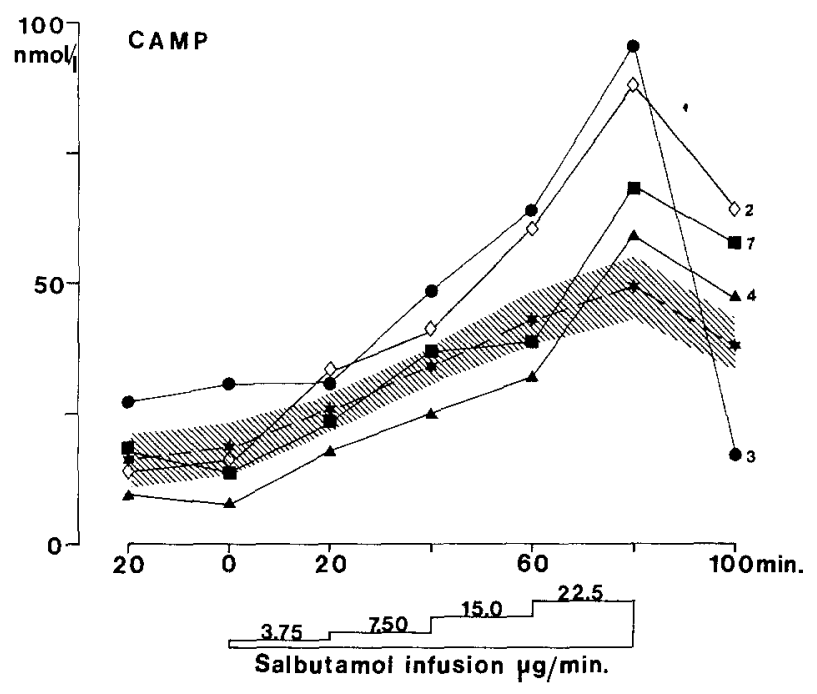

Fig. 2. Effect of salbutamol om plasma cyclic AMP levels in 4 nondiabetic (Mean \pm SEM. - shaded area) and 4 diabetic women (numbers refer to patient numbers in Table 1)

Table 2. Maximal increase in plasma metabolite levels in diabetic and non-diabetic women due to salbutamol infusion. $\bar{X} \pm S E M$. Number of patients are shown in parenthesis

\begin{tabular}{|c|c|c|c|}
\hline & Non-diabetic & Diabetic & p-value \\
\hline $\begin{array}{l}\text { Cyclic AMP } \\
\text { nmol } / 1 \\
\text { Glucose }\end{array}$ & $32.0 \pm 3.2(4)$ & $60.2 \pm 4.4(4)$ & $<0.01$ \\
\hline $\begin{array}{l}\mathrm{mmol} / 1 \\
\mathrm{FFA}\end{array}$ & $1.70 \pm 0.50$ & $3.99 \pm 0.37(7)$ & $<0.01$ \\
\hline $\begin{array}{l}\mathrm{mmol} / 1 \\
\text { Glycerol }\end{array}$ & $0.41 \pm 0.04$ & $0.88 \pm 0.11$ & $<0.05$ \\
\hline $\begin{array}{l}\mathrm{mmol} / 1 \\
3-\mathrm{HB} \\
(\mathrm{mmol} / 1)\end{array}$ & $\begin{array}{l}0.096 \pm 0.010(5) \\
0.45+0.05\end{array}$ & $0.217 \pm 0.021(7)$ & $\begin{array}{l}<0.01 \\
<0.05\end{array}$ \\
\hline
\end{tabular}



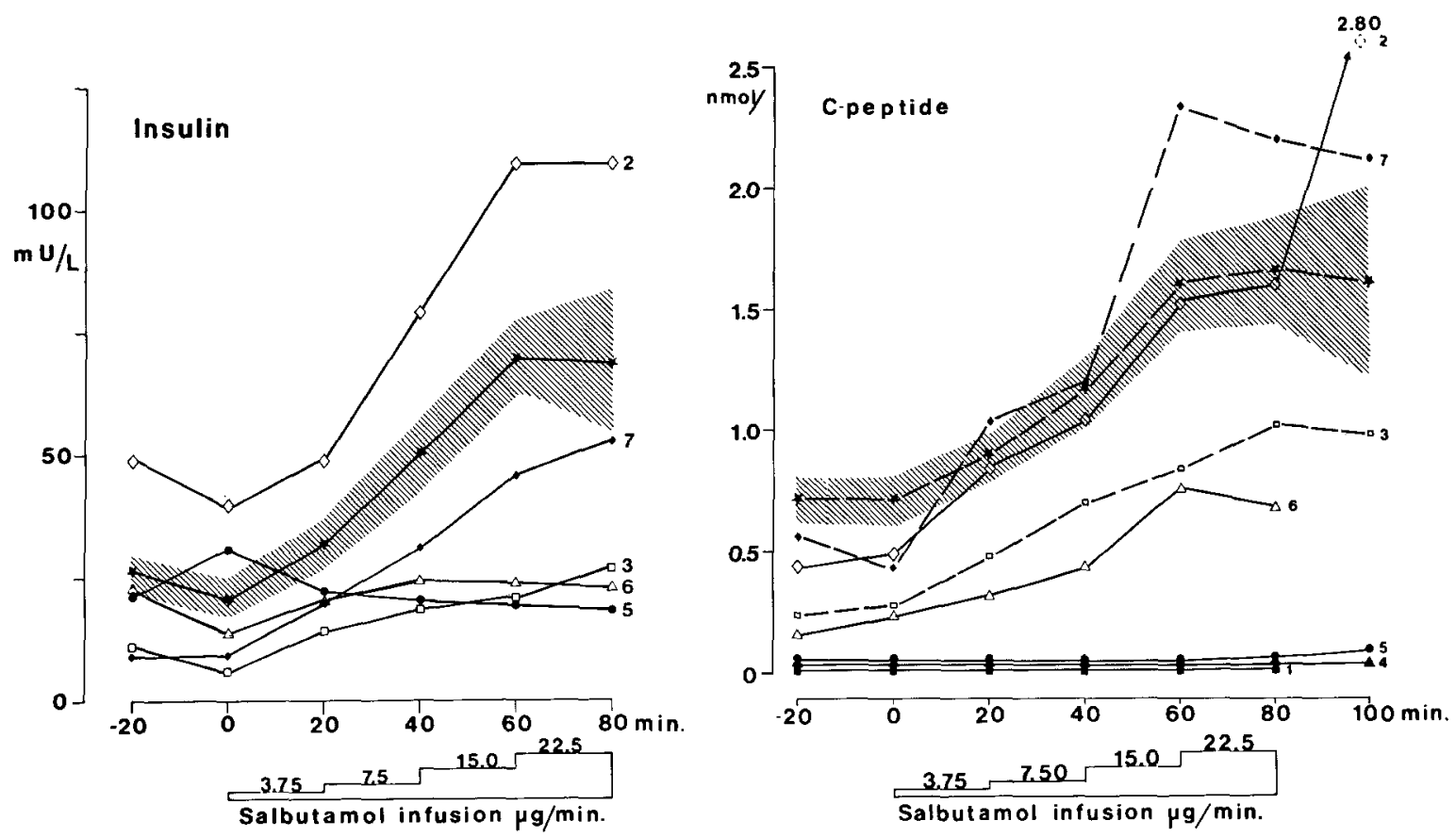

Fig. 3 a. Effect of salbutamol on plasma immunoreactive insulin. Values for 5 non-diabetic women given as mean \pm SEM. (shaded area). The values for 5 diabetic women are presented individually. $\mathbf{b}$ Effect of salbutamol on plasma C-peptide levels. Values for 5 non-diabetic women are given as mean $\pm S E M$. (shaded area). The values for 7 diabetic women are given individually

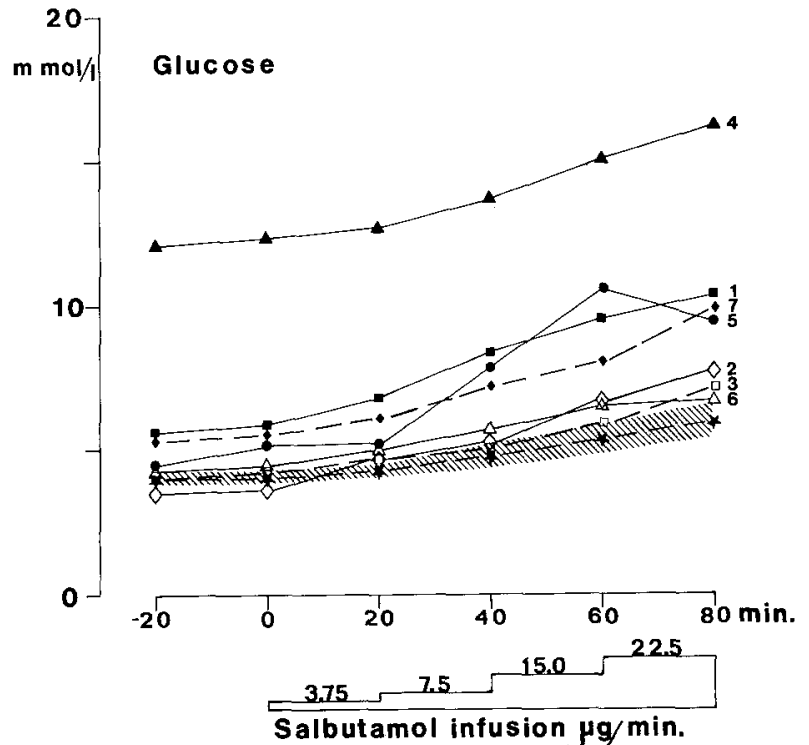

Fig. 4. Effect of salbutamol in plasma glucose levels. For details see Figure $3 b$

blood pressure was $11 \mathrm{~mm} \mathrm{Hg}(9 \%)$. Fetal heart rate showed less pronounced changes than maternal heart rate. Thus the peak increase in fetal heart rate amounted to 16 beats/min $(11 \%)$ while maternal heart rate increased maximally by 37 beats/min $(42 \%)$.
Cyclic AMP

Basal cyclic AMP levels were similar in the diabetic and non-diabetic groups (17 \pm 4 vs. $17 \pm 5 \mathrm{nmol} / \mathrm{l}$; mean \pm SEM, $n=4$ ). After $20 \mathrm{~min}$ of the lowest dose a significant increase was found. The maximal increase over basal (Table 2) was significantly higher in the diabetic group.

\section{Insulin and C-Peptide}

The plasma level of insulin and C-peptide rose with increasing salbutamol dose in the non-diabetic controls. After $60 \mathrm{~min}$ the mean insulin concentration was $70 \pm 6 \mathrm{mU} / \mathrm{l}$ compared with a basal level of $23 \pm$ $3 \mathrm{mU} / 1(\mathrm{p}<0.01)$. The mean basal C-peptide level was $0.67 \pm 0.10 \mathrm{nmol} / 1$ and the peak value at $80 \mathrm{~min}$ was $1.59 \pm 0.25 \mathrm{nmol} / 1(\mathrm{p}<0.01)$. The increase in C-peptide level was significant $(\mathrm{p}<0.01)$ already after $20 \mathrm{~min}$.

In three of the diabetic women (pat. no. $1,4,5$ ) C-peptide levels were almost undetectable (Fig. 3). Two of the diabetic women $(2,7)$ showed a marked insulin and C-peptide response to salbutamol (Fig. 3). One of these women was grossly obese while the other was a gestational diabetic (Table 1). The last women in the diabetic group $(3,6)$ showed measurable but weak insulin and $\mathrm{C}$-peptide responses, suggesting the presence of a weak $\beta$-cell function. 

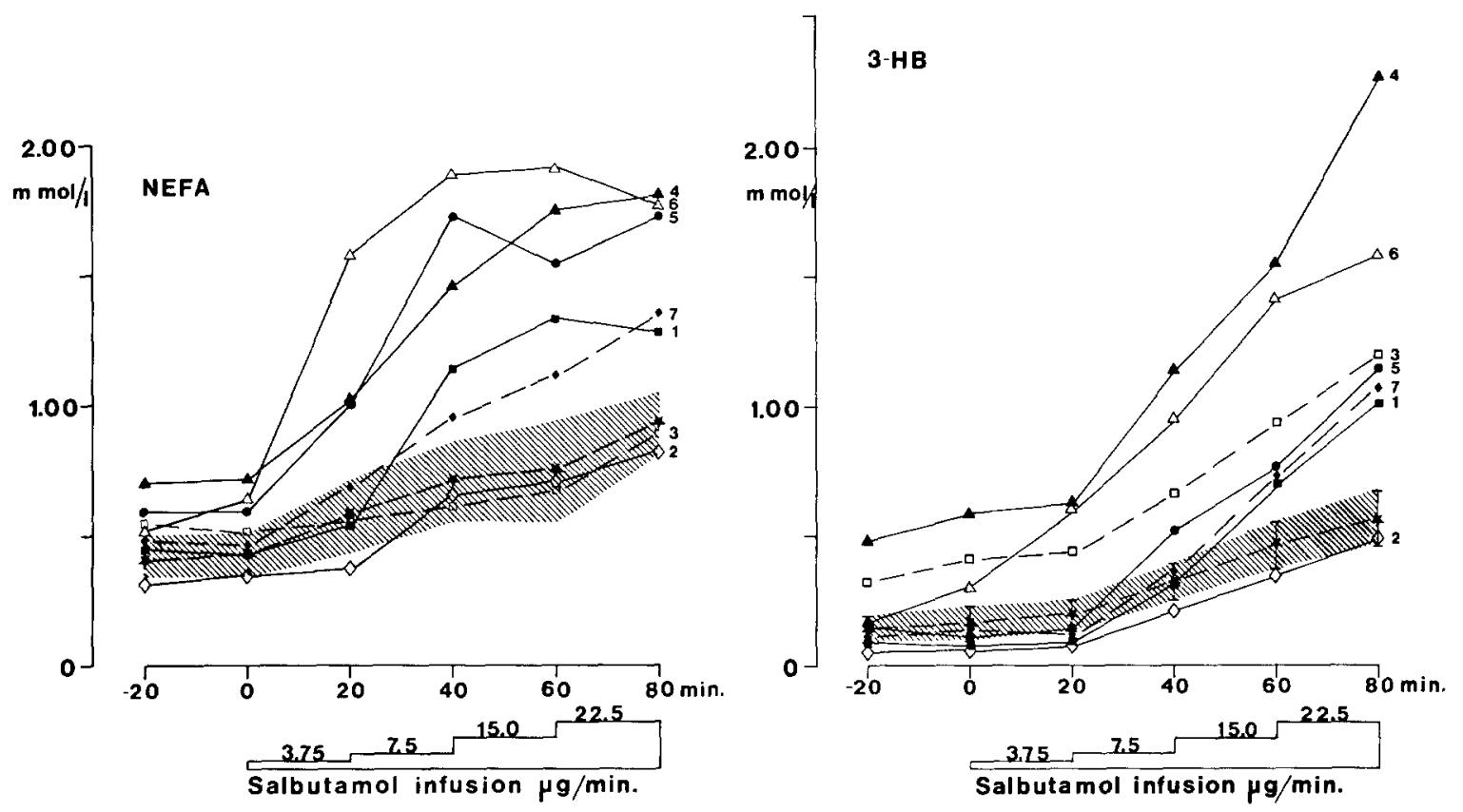

Fig. 5a The effect of salbutamol on plasma NEFA. For details see Figure $3 \mathbf{b}$ b The effect of salbutamol on the plasma level of $3-$ hydroxybutyrate (3-HB). For details see Figure $3 \mathrm{~b}$

\section{Glucose and Lactate}

In the control group plasma glucose rose from $4.0 \pm$ $0.16 \mathrm{mmol} / 1$ to $5.7 \pm 0.35 \mathrm{mmol} / \mathrm{l}$ at the end of the infusion. The response was more marked in the diabetic women, in whom the plasma glucose increased from $5.81 \pm 1.02$ to $9.80 \pm 1.38 \mathrm{mmol} / 1$ (Fig. 4, Table 2). Blood lactate levels were similar in nondiabetic and diabetic women (Basal values: $1.12 \pm$ $0.10 \mathrm{mmol} / 1$ in controls vs. $1.24 \pm 0.12 \mathrm{mmol} / 1$ in the diabetics; peak values after $80 \mathrm{~min}: 1.98 \pm 0.34$ vs. $2.18 \pm 0.22 \mathrm{mmol} / \mathrm{l})$.

\section{Glycerol, NEFA and 3-Hydroxybutyrate (3-HB)}

The basal level of glycerol was $0.64 \pm 0.06 \mathrm{mmol} / 1 \mathrm{in}$ the non-diabetic and $0.12 \pm 0.22 \mathrm{mmol} / 1$ in the diabetic women $(p<0.01)$. Salbutamol induced a significant increase in plasma glycerol, which was significantly larger in the diabetic group of women (Table 2). The results with NEFA and 3-HB are illustrated in Figure 5 ( $a$ and $b$ ). Also for these variables the diabetic women had higher basal values and showed a significantly larger salbutamol-induced increase (Table 2).

\section{Inter-Relationship between the Different Variables}

In order to study the relationship between the salbutamol effects on the separate variables correlation
Table 3. Plasma metabolite levels at the end of salbutamol infusion and $20 \mathrm{~min}$ after infusion (Mean $\pm \mathrm{SD}$ ). The table is based on results on 4 diabetic (n. 2, 3, 4, 7) and 4 non-diabetic $[9,10,11$, 12] patients. Statistical analysis revealed no significant differences between the patient groups. Therefore the pooled data are given

\begin{tabular}{lccl}
\hline Metabolite & End of infusion & After infusion & p-value \\
\hline Cyclic AMP $^{\mathrm{a}}$ & $63.8 \pm 7.3$ & $41.8 \pm 5.7$ & $<0.05$ \\
Glycerol $^{\mathrm{b}}$ & $0.23 \pm 0.04$ & $0.15 \pm 0.02$ & $<0.05$ \\
FFA $^{\mathrm{b}}$ & $1.00 \pm 0.12$ & $0.86 \pm 0.13$ & N.S. \\
3-HB $^{\mathrm{b}}$ & $0.90 \pm 0.21$ & $0.94 \pm 0.24$ & N.S. \\
Glucose $^{\mathrm{b}}$ & $7.76 \pm 1.24$ & $7.88 \pm 1.33$ & N.S. $^{d}$ \\
Lactate $^{\mathrm{b}}$ & $2.08 \pm 0.24$ & $2.09 \pm 0.22$ & N.S. $^{d}$ \\
Insulin $^{\mathrm{c}}$ & $64 \pm 11$ & $64 \pm 11$ & N.S. \\
\hline
\end{tabular}

a $\mathrm{nmol} / \mathrm{l} \quad \mathrm{b}^{\mathrm{mmol} / \mathrm{l}} \mathrm{c} \mathrm{mU} / \mathrm{l}$ d not significant

analysis was performed. The rise in glucose was significantly correlated with the rise in cyclic AMP $(\mathrm{r}=0.84, \mathrm{p}<0.01)$. A weak correlation between cyclic AMP and glycerol $(\mathrm{r}=0.58, \mathrm{p}<0.05)$ was found. On the other hand, there was no significant relationship between cyclic AMP and increases of NEFA of 3-HB, insulin or C-peptide.

The rise in NEFA, glycerol and 3-HB were all correlated ( $p<0.01$ or better). There were weak positive correlations between the rise in glucose and the rise in the three lipid metabolites $(p<0.05)$.

Finally, the relationship between the changes (or absolute levels) of insulin and the other variables was estimated. Neither cyclic AMP nor glucose was signi- 
ficantly correlated with insulin. However, the increase in all the lipid variables (glycerol, NEFA, 3$\mathrm{HB})$ were inversely correlated $(\mathrm{r}=-0.64,-0.65$, $-0.63)$ with the salbutamol-induced insulin rise ( $\mathrm{p}<$ 0.02 ).

\section{Responses after Stopping the Salbutamol Infusion}

The cardiovascular responses (Fig. 1) as well as the responses in cyclic AMP and glycerol (Table 3) were all decreased within 20 min after infusion. However, all the other variables remained elevated for at least 20 min after stopping the infusion.

\section{Discussion}

The present results demonstrate that salbutamol has significant cardiovascular and metabolic effects in doses used clinically in obstetric practice.

The cardiovascular effects were similar to those reported previously [25, 27, 29]. The earliest observed and most pronounced effect was a fall in diastolic blood pressure. The increase in maternal heart rate was less pronounced and appeared to require larger doses. The cardiac $\beta$-adrenoceptors are mainly of the $\beta_{1}$-type, while there are $\beta_{2}$-adrenoceptors mediating vasodilatation in several vascular beds $[20,43]$. The rise in heart rate following administration of salbutamol may be due to reflex activation of the heart rather than to a direct cardiostimulant effect of salbutamol [10]. It is interesting to note that fetal heart rate was affected less than maternal heart rate. Possibly, the cardiovascular reflexes are less well developed in the fetus than in the adult even though $\beta$-receptor in fetal heart has been detected early in gestation [36]. There were no significant differences in the cardiovascular responses to salbutamol in diabetic and nondiabetic women, suggesting that there is no generalized difference in $\beta$-receptor sensitivity in the two groups.

The present study was focused on the metabolic effects of salbutamol infusion in pregnant women. All the metabolic variables examined were stimulated by salbutamol. It is generally agreed that cyclic AMP mediates the stimulation of glycogenolysis, lipolysis and ketogenesis as well as insulin release caused by $\beta$-adrenoceptor agonists [35]. The basal plasma cyclic AMP levels in pregnant women reported here agree well with values found by Yuen et al. [41], but are lower than those found by Ling et al. [26]. They are also similar to those found in nonpregnant human subjects $[3,7]$. There are several reports that plasma cyclic AMP levels are elevated following increases in endogenous or exogenous ca- techolamines $[3,6,12,18]$. The present study shows that elevated plasma cyclic AMP levels can be demonstrated also following the administration of the synthetic non-catecholamine $\beta_{2}$-adrenoceptor stimulating drug salbutamol. Little is known about the sources of plasma cyclic AMP, although the liver appears to be an important source $[7,19,24]$. Indeed Exton et al. [11] have found that the perfused liver excretes substantial amounts of cyclic AMP into the perfusate following the addition of glycogenolytic hormones. These authors also report a better correlation between the glycogenolytic effect and the rise of cyclic AMP in the perfusate than in the liver tissue. We found a good correlation between induced changes in cyclic AMP and induced changes in glucose, which is compatible with these findings. In contrast lipid metabolites did not correlate with cyclic AMP in agreement with earlier reports $[12,38]$. It is probable that adipose tissue does not contribute significantly to plasma cyclic AMP $[12,13,18,38]$.

We have found that the salbutamol-induced rise in plasma cyclic AMP was significantly greater in diabetics than in non-diabetics, just as others have reported an increased responsiveness of other metabolic variables to $\beta$-receptor stimulation in diabetes $[2,5,14]$. The finding may be related to the increased release of glucagon in diabetes $[5,14]$, since glucagon is known to enhance plasma cyclic AMP $[6,11,19$, $24,35]$. Another possibility is that cyclic AMP production may be, at least partly, governed by insulin. Insulin has been shown to antagonize stimulation of cyclic AMP production in several tissues including liver and adipose tissue $[11,35]$. Furthermore, the insulin level after salbutamol may in turn be governed by cyclic AMP since $\beta$-receptor agonists are known to cause insulin release secondary to pancreatic cyclic AMP elevations [30]. Since cyclic AMP may cause insulin release and insulin may depress cyclic AMP formation the absence of a clear relationship between the two is understandable.

Salbutamol induced increases of plasma glycerol, NEFA, 3-HB, glucose and lactate have been reported earlier in pregnant women $[28,39]$. A rise in insulin levels following salbutamol was also reported by these authors. Since insulin is known to modulate carbohydrate and lipid metabolism we expected that the responses to salbutamol would be more pronounced in diabetics with a deficient pancreatic $\beta$-cell function and/or decreased insulin sensitivity. The diabetic women in the present study were a rather heterogenous group. Three of the women appeared to have no discernible $\beta$-cell function as judged from absent insulin and C-peptide responses to salbutamol and low basal C-peptide levels. Two of the diagnosed gestational diabetics had molar C-peptide/insulin ra- 
tios and salbutamol induced insulin and C-peptide responses similar to the controls. The remaining two women were intermediary between these two extremes.

In the diabetic women the salbutamol-induced increase in plasma glucose was significantly larger than in controls. This may be due both to a lack of circulating insulin and to insulin insensitivity in this group. The above mentioned increased glucagon release in diabetic patients may also have contributed $[5,14]$. The decreased glucose elimination of the diabetics is one likely cause of the larger glucose increase following salbutamol. Furthermore, an increased glucose production may have occurred. The positive correlation between glucose and cyclic AMP and the significantly larger cyclic AMP response in the diabetic group suggests that such a mechanism might contribute. Diabetic women may therefore have a decreased insulin response both in peripheral glucose utilizing tissues and in the liver where glucose production occurs. This would render them more sensitive to fluctations in glucose following $\beta$-adrenoceptor stimulation.

The lipid metabolites also showed larger changes following salbutamol in the diabetic than in the nondiabetic group. The explanation in this case appears to be both a decreased insulin response and a decreased insulin sensitivity. Thus, there was a significant negative correlation between the plasma insulin and the salbutamol-induced responses. Furthermore, the reponse in the non-diabetic group appeared to be lower than in the diabetic for a given insulin level. On the other hand, glucagon does not appear to contribute significantly to the lipolytic response [14].

The very marked metabolic responses in diabetic women argues for cautious use of the drug in diabetics. At the end of the $80 \mathrm{~min}$ infusion period NEFA and 3-HB levels approached $2 \mathrm{mmol} / \mathrm{l}$. Furthermore, the level of these metabolites did not return to basal levels rapidly after infusion. Since high levels of FFA may further impair peripheral glucose utilization [33] this may have adverse effects in some women receiving prolonged salbutamol infusions. Similarly, increased production of 3-HB may give rise to acidosis, that, if prolonged, may have deleterious consequences. Indeed, after completion of this study two case reports of salbutamol-induced diabetic ketoacidosis have appeared in press $[23,40]$. We did not find any difference in the cardiovascular responses in the two groups of pregnant women. Therefore assessment of cardiovascular variables may not be sufficient to warn against metabolic hyperreactivity to salbutamol. Thus it may be advisable to take frequent determinations of some metabolic variable such as glucose in diabetic women receiving salbutamol to guard against unwanted metabolic responses that may also affect the fetus.

Acknowledgements. This study was supported by grants from the Swedish Medical Research Council (Proj. no. 04X-2553, 19P4106, 19X-03787), Tielman's Fund for Paediatric Research, Expressen's Fund for Paediatric Research and by Stiftelsen Allmänna Barnbördshusets Minnesfond.

\section{References}

1. Andersson, K.-E., Bengtsson, L. Ph., Gustafson, I., Ingemarsson, I.: The relaxing effect of terbutaline on the human uterus during term labour. Am. J. Obstet. Gynecol. 121, 602-609 (1975)

2. Baker, L., Kaye, R., Haque, N.: Metabolic homeostatis in juvenile diabetes mellitus. II. Increased ketone responsiveness to epinephrine. Diabetes 18, 421-427 (1969)

3. Ball, J.H., Kaminsky, N. I., Hardman, J.G., Broadus, A. E., Sutherland, E.W., Liddle, G.W.: Effects of catecholamines and adrenergic-blocking agents on plasma and urinary cyclic nucleotides in man. J. Clin. Invest. 51, 2124-2129 (1972)

4. Bär, H.-P.: Cyclic nucleotides and smooth muscle. Adv. Cyclic Nucleotide Res. 4, 195-238 (1974)

5. Benson, J.W., Johnston, D. G., Palmer, J.P., Werner, P.L., Ensinck, J. W.: Glucagon and catecholamine secretion during hypoglycemia in normal and diabetic man. J. Clin. Endocrinol. Metab. 44, 459-464 (1977)

6. Brodows, R. G., Ensinck, J.W., Campbell, R. G.: Mechanism of plasma cyclic AMP response to hypoglycemia in man. Metabolism 25, 659-663 (1976)

7. Broadus, A. E., Kaminsky, N. I., Hardman, J. G., Sutherland, E. W., Liddle, G. W.: Kinetic parameters and renal clearances of plasma adenosine $3^{\prime}, 5^{\prime}$-mono-phosphate and guanosine $3^{\prime}, 5^{\prime}$-monophosphate in man. J. Clin. Invest. 49, 2222-2236 (1970)

8. Brown, B. L., Ekins, R. P., Albano, J. D. M.: Saturation assay for cyclic AMP using endogenous binding protein. Adv. Cyclic Nucleotide Res. 2, 25-40 (1972)

9. Cramp, D. G.: Automated enzymatic fluorimetric method for the determination of pyruvic and lactic acids in blood. J. Clin. Pathol. 21, 171-174 (1968)

10. Dunlop, D., Shanks, R. G.: Selective blockade of adrenoceptive $\beta$-receptors in the heart. Br. J. Pharmacol. 32, 201-210 (1968)

11. Exton, J.H., Lewis, S.B., Ho, R. J., Park, C. R.: The role of cyclic AMP in the control of hepatic glucose production by glucagon and insulin. Adv. Cyclic Nucleotide Res. 1, 91-101 (1972)

12. Farnebo, L. O., Fredholm, B. B., Hamberger, B., Hjemdahl, P., Westman, L.: Cyclic AMP and metabolic substrates in hemorrhagic shock of the rat. Acta Chir. Scand. 143, 9-14 (1977)

13. Fredholm, B. B., Belfrage, E., Blaschke, E.: Changes in ATP and cyclic nucleotide levels during sympathetic nerve stimulation in canine subcutaneous adipose tissue in situ. Acta Physiol. Scand. 99, 313-322 (1977)

14. Gerich, J. E., Lorenzi, M., Tsalikian, E., Koram, J. H.: Studies on the mechanism of epinephrine-induced hyperglycemia in man. Evidence for participation of pancreatic glucagon secretion. Diabetes 25, 65-71 (1977)

15. Heding, L. G.: Determination of free and antibody-bound insulin in insulin treated diabetic patients. Horm. Metab. Res. 1, 145-146 (1969) 
16. Heding, L. G.: Radioimmunological determination of human C-peptide in serum. Diabetologia 11, 541-548 (1975)

17. Hüter, J., Rippert, Ch., Meyer, C.: Wehenhemmung mit welchem Beta-minetikum (Berotec $^{\mathrm{R}}$, Ritodrine ${ }^{\mathrm{R}}$, Dilatol ${ }^{\mathrm{R}}$ ). Z. Geburtsh. u. Frauenheilk. 32, 97-103 (1972)

18. Issekutz, T.B.: Estimation of cyclic AMP turnover in normal and methylprednisolone-treated dogs: effect of catecholamines. Am. J. Physiol. 229, 291-297 (1975)

19. Jerums, G., Hardy, K. J., Eisman, J. A.: The cyclic AMP response to glucagon. Comparisons of tissue and plasma cyclic AMP levels in the rabbit. Diabetes 26, 81-88 (1977)

20. Lands, A.M., Arnold, A., McAuliff, J.P., Ludena, F.P., Brown, Jr., T. G.: Differentiation of receptor systems activated by symathomimetic amines. Nature 214, 597-598 (1967)

21. Laurell, S., Tibbling, G.: An enzymatic fluorimetric micromethod for the determination of glycerol. Clin. Chim. Acta 13, 317-322 (1966)

22. Laurell, S., Tibbling, G.: Colorimetric microdetermination of free fatty acids in plasma. Clin. Chim. Acta 16, 57-62 (1967).

23. Leslie, D., Coats, P.M.: Salbutamol-induced diabetic ketoacidosis. Br. J. Med. 1977 IV, 768

24. Liljenquist, J.E., Bomboy, J.D., Lewis, S. B., Sinclair-Smith, B. C., Felth, P.W., Lacy, W.W., Crofford, O.B., Liddle, G. W.: Effect of glucagon on net splanchnic cyclic AMP production in normal and diabetic men. J. Clin. Invest. 53, 198-204 (1974)

25. Liggins, G. C., Vaughan, G. S.: Intravenous infusion of salbutamol in the management of premature labour. J. Obstet. Gynaecol. Br. Cwlth 80, 29-32 (1973)

26. Ling, W. Y., Marsh, J. M., LeMaire, W. J.: Adenosine-3',5'monophosphate in the plasma from human pregnancy. J. Clin. Endocrinol. Metab. 44, 514-519 (1977)

27. Lunell, N. O., Joelsson, I., Björkman, U., Lamb, P., Persson, B.: The use of salbutamol in obstetrics. Acta Obstet. Gynecol. Scand. 55, 333-336 (1976)

28. Lunell, N.O., Joelsson, I., Larsson, A., Persson, B.: The immediate effect of a $\beta$-adrenergic agonist (salbutamol) on carbohydrate and lipid metabolism during the third trimester of pregnancy. Acta Obstet. Gynecol. Scand. 56, 475-478 (1977)

29. McDevitt, D. G., Wallace, R.J., Roberts, A., Withfield, C. R.: The uterine and cardiovascular effects of salbutamol and practolol during labour. Br. J. Obstet. Gynaecol. 82, 442-448 (1975)

30. Montague, W., Howell, S. L.: Cyclic AMP and the physiology of the islet of Langerhans. Adv. Cyclic Nucleotide Res. 6, 201-243 (1975)
31. Nochimson, D.J., Riffel, H.S., Yeh, S.-Y., Kreitzer, M.S., Paul, R. H., Hon, E. H.: The effects of ritodrine hydrochloride on uterine activity and the cardiovascular system. Am. J. Obstet. Gynaecol. 118, 523-528 (1974)

32. Persson, B.: Determination of plasma acetoacetate and D- $\beta$ hydroxybutyrate in newborn infants by an enzymatic fluorimetric micromethod. Scand. J. Clin. Lab. Invest. 25, 9-18 (1969)

33. Randle, P. J., Garland, P.B., Hales, C. N., Newsholme, E. A.: The glucose fatty acid cycle. Lancet 1963 I, 785-789

34. Renaud, R., Irrman, M., Gander, R., Flynn, M. J.: The use of ritodrine in the treatment of premature labour. J. Obstet. Gynaecol. Br. Cwith. 81, 182-186 (1974)

35. Robison, G.A., Butcher, R.W., Sutherland, E.W.: Cyclic AMP. New York: Academic Press 1971

36. Rudolph, A. M., Heymann, M. A.: Fetal and neonatal circulation and respiration. Annu. Rev. Physiol. 36, 187-207 (1974)

37. Steel, J.M., Parboosingh, J.: Insulin requirements in pregnant diabetics with premature labour controlled by ritodrine. $\mathrm{Br}$. Med. J. 1977 I, 880

38. Strange, R.C., Rowe, M.J., Mjøs, O.D., Oliver, M. F.: The effect of antilipolytic agents on cyclic AMP, free fatty acid and total catecholamine concentrations in plasma. Acta Med. Scand. 199, 421-424 (1976)

39. Thomas, D. J. B., Dove, A. F., Alberti, K. G. M. M.: Metabolic effects of salbutamol infusion during premature labour. Br. J. Obstet. Gynaecol. 84, 497-499 (1977)

40. Thomas, D. J. B., Gill, B., Brown, P., Stubbs, W.A.: Salbutamol-induced diabetic ketoacidosis Br. Med. J. 1977 IV, 438

41. Yuen, B. H., Wittman, B., Staley, K.: Cyclic adenosine 3',5'monophosphate (CAMP) in pregnancy body fluids during normal and abnormal pregnancy. Am. J. Obstet. Gynaecol. 125, 597-602 (1976)

42. White, P.: Pregnancy and diabetes, medical aspects. Med. Clin. North Am. 49, 1015-1024 (1965)

43. Ảblad, B., Carlsson, E., Dahlöf, C., Ek, L.: Some aspects of the pharmacology of $\beta$-adrenoceptor blockers. Drugs (Suppl. 1.) 11, 100-111 (1976)

Received: August 31, 1977,

and in revised form: November 28, 1977

Bertil B. Fredholm, M. D.

Department of Pharmacology

Karolinska Institute

S-104 01 Stockholm 60, Sweden 